\title{
TINJAUAN YURIDIS TERHADAP NOODWEER \\ SEBAGAI UPAYA PEMBELAAN YANG SAH
}

\author{
Dwi Dasa Suryantoro
}

\author{
STAI Nurul Huda Kapongan Situbondo \\ Jalan Habibi No.02 Kapongan Situbondo. 68362. \\ Email: dasadwi90@gmail.com
}

\begin{abstract}
One of the reasons is Criminal Defense removal emergency/Noodweer, in this author's analysis on how to review judicially against Noodweer legitimate defense effort as legally. The analysis in this research article using normative juridical approach to legal materials-based good literature as well as legislation. Noodweer is any act or conduct of a person to conduct the defence in an emergency due to an attack that is immediately or are against the law, where such attacks could threaten the safety of the body, lives, property and honor. It is also set forth in the book of the law of criminal law on article 49 paragraph 1 of the criminal code regulates about deeds/emergency Defense for oneself as well as others, honor, decency, or the property itself or others, due to an attack or the threat of attack is very close. But the emergency Defense must satisfy the elements of a defense emergency and not contrary to the purposes of the law i.e. fairness, certainty and benefit.
\end{abstract}

Key words : Lawful Defense Noodweer.

\begin{abstract}
ABSTRAK
Salah satu alasan penghapusan pidana adalah Pembelaan secara darurat/noodweer, dalam hal ini penulis melakukan analisa mengenai bagaimana tinjauan yuridis terhadap noodweer sebagai upaya pembelaan yang sah secara hukum. Analisa dalam artikel penelitian ini menggunakan pendekatan yuridis normatif berbasis bahan hukum baik literatur maupun perundang-undangan. Noodweer adalah segala tindakan atau perbuatan seseorang untuk melakukan pembelaan secara darurat karena adanya serangan yang bersifat seketika atau bersifat melawan hukum, dimana serangan tersebut dapat mengancam keselamatan pada tubuh, nyawa, harta benda dan kehormatan. Hal ini juga diatur dalam Kitab Undang-undang Hukum Pidana pada Pasal 49 ayat 1 KUHP mengatur tentang perbuatan/pembelaan darurat untuk diri sendiri maupun orang lain, kehormatan, kesusilaan, atau harta benda sendiri maupun orang lain, karena adanya serangan atau ancaman serangan yang sangat dekat. Namun pembelaan secara darurat tersebut harus memenuhi unsur-unsur pembelaan darurat dan tidak bertentangan dengan tujuan hukum yaitu keadilan, kepastian dan kemanfaatan.
\end{abstract}

Kata Kunci : Noodweer Pembelaan yang Sah.

\section{PENDAHULUAN}

Hukum pidana merupakan sebagian dari salah satu hukum yang ada di Indonesia, namun secara hakekatnya tidak berbeda dengan hukum-hukum lainnya yaitu semua hukum memuat tentang ketentuan untuk terjaminnya norma-norma yang terdapat dalam hukum dapat ditaati oleh setiap manusia. Namun dalam satu hal hukum pidana itu ada perbedaan dengan hukumhukum yg lain pada umumnya yaitu bahwa dalam hukum pidana terdapat suatu kesengajaan untuk memberikan akibat hukum yaitu pemberian hukuman/sanksi atau 
penderitaan kepada setiap subjek hukum pidana yang telah melakukan pelanggaran dan atau kejahatan dalam kehidupan bermasyarakat sebagaimana yang telah diatur dalam undang-undang.

Selain itu dalam hukum pidana juga dikenal dengan adanya alasan penghapus pidana, dimana alasan penghapus pidana berpangkal pada ajaran dualitis yang memisahkan unsur tindak pidana hanya berkaiatan dengan unsur pertanggung jawaban pidana. ${ }^{1}$

Dalam hukum pidana di Indonesia tidak hanya mengatur tentang penjatuhan pidana saja namun juga mengatur tentang adanya suatu pembelaan darurat sebagai upaya pemebalaan yang sah secara hukum, yang sering kita sebut sebagai noodweer, dimana mengenai noodweer ini telah ditaur dalam hukum positif yaitu terdapat pada Kitab Undnag-Undang Hukum Pidana pada pasal 49 ayat 1 KUHP mengatur tentang perbuatan / pembelaan darurat untuk diri sendiri maupun orang lain, kehormatan, kesusilaan, atau harta benda sendiri maupun orang lain, karena adanya serangan atau ancaman serangan yang sangat dekat.

Ketika kita melihat bunyi dari Pasal 49 ayat 1 KUHP, tidak kita temukan perkataan tentang noodweer, namun perkataan tersebut terdapat di dalam Memorie Van Toelichting mengenai pembentukan Pasal 49 ayat 1 KUHP yang mengatakan bahwa tidaklah terdapat suatu noodweer tanpa adanya suatu :

1. Serangan yang bersifat melawan hukum

2. Bahaya yang bersifat langsung bagi tubuh, kehormatan atau benda milik sendiri atau milik orang lain.

3. Keperluan untuk melakukan perbuatan yang bersangkutan untuk meniadakan bahaya yang nyata yang telah ditimbulkan oleh serangan tersebut, yang telah tidak dapat ditiadakan dengan cara yang lain. ${ }^{2}$

Noodweer itu sendiri merupakan suatu perkataan yang digunakan masyarakat untuk menyebut lembaga "noodzakelijke verdediging tegen agenblijkkelijk wederechtelijke aanranding"3 yang artinya lembaga pembelaan yang perlu dilakukan terhadap serangan yang bersifat seketika dan yang bersifat melawan hukum.

Jadi dalam rumusan Pasal 49 ayat 1 KUHP apabila kepentingan-kepentingan hukum dari subjek hukum mendapatkan adanya serangan yang sifatnya melawan hukum maka pada prinsipnya setiap orang dapat dibenarkan dalam melakukan pembelaan terhadap serangan tersebut, meskipun dengan cara yang merugikan kepentingan hukum dari penyerangnya, namun dalam keadaan biasa cara tersebut merupakan suatu perbuatan yang dilarang dimana pelakunya telah diancam

\footnotetext{
${ }^{1}$ M. Ruba i, (2015), Buku Ajar Hukum Pidana, Malang; Media Nusa Creative, Hlm. 236

2 P.A.F. Lamintang, P.A.F, (2014), Dasar-Dasar Hukum Pidana di Indonesia, Jakarta Timur; Sinar Grafika. Hlm. 470

${ }^{3}$ Ibid. Hlm. 470
} 
dengan sesuatu hukuman. Disinilah penulis tertarik untuk mengkaji secara yuridis mengenai noodweer dapat dijadikan sebagai upaya pembelaan yang sah.

Dari latar belakang tersebut Penulis tertarik untuk melakukan sebuah analisa secara yuridis normatif terhadap pembelaan secara darurat/noodweer. Manfaat yang dapat diambil dari artikel ini adalah agar masyarakat dapat mengetahui mengenai pembelaan darurat yang diperbolehkan oleh hukum, dan juga dapat dijadikan bahan oleh mahasiswa dan praktisi hukum sserta bermanfaat untuk pengembangan teori hukum dan konsep hukum dalam penerapan noodweer di masyarakat.

Tujuan Penulisan ini untuk mengetahui dan menganalisa secara yuridis yang berkaitan dengan pembelaan darurat apakah pembelaan darurat dapat dijadikan suatu upaya pembelaan yang sah secara hukum.

Adapun Rumusan masalah yang dapat penulis sajikan dalam tulisan ini adalah bagaimana tinjauan yuridis terhadap Pembelaan darurat/noodweer sebagai upaya pembelaan yang sah secara hukum?

Metode penelitian merupakan suatu tahapan dalam melakukan suatu kegiatan penelitian sebagaimana nantinya dapat menjalankan fungsi penelitian, dimana fungsi penelitian untuk mendapatkan suatu kebenaran. ${ }^{4}$ Suatu kebenaran harus bersumber pada ilmu pengetahuan yaitu dari mana sumber-sumber pengetahuan itu diperoleh, apakah sumber pengetahuan tesebut dapat dipercaya atau tidak. ${ }^{5}$ Dengan demikian tanpa adanya suatu metode penelitian, peneliti tidak akan pernah mendapatkan sumber-sumber pengetahuan dalam penelitiannya sehingga kebenaran yang dicari sebagaimana fungsi dari penelitian itu sendiri tidak akan pernah mendapatkan kebenaran. Penelitian ini menggunakan penelitian hukum yuridis normatif dimana penelitian ini mempunyai sifat deskriptif, yang maksudnya pendekatan berdasarkan peraturan perundang-undangan serta hukum yang berkaitan erat dengan masalah yang akan diteliti yang bersumber pada fakta yang sebenarnya di dalam masyarakat dan bahan pustaka atau data sekunder. Pendekatan yang penulis lakukan ini berdasarkan peraturan perundangundangan dan teori-teori, asas-asas hukum pidana, doktrin hukum pidana, literatur/bukubuku hukum pidana di Indonesia.

\section{PEMBAHASAN}

Noodweer merupakan suatu pembelaan darurat terhadap serangan, dimana serangan tersebut harus bersifat seketika dan bersifat melawan hukum. Nood artinya darurat sedangkan weer mempunyai arti darurat, sehingga dapat diartikan bahwa noodweer adalah pembelaan yang dilakukan secara darurat oleh setiap orang terhadap serangan

\footnotetext{
${ }^{4}$ Peter Mahmud Marzuki, (2013), Penelitian Hukum, Jakarta; Kencana Perdana Media Group. Hlm. 20

${ }^{5}$ Ibid. Hlm 20
} 
dari orang lain yang bersifat seketika dan melawan hukum.

Dasar hukum dari pembelaan darurat ini terdapat pada Pasal 49 ayat 1 KUHP, dalam rumuan pasal tersebut oleh pembentuk Undangundang Hukum Pidana dipergunakan perkataan "annrandig" jika diterjemahkan ke dalam bahasa Indonesia yang artinya "serangan", jika kita melihat kalimat serangan yang ada pada Pasal 49 ayat 1 KUHP tersebut jangan selalu diartikan sebagai tindakan kekerasan, akan tetapi tindakan kekerasan disini mempunyai arti tindakan yang merugikan kepentingan hukum orang lain seperti tubuh atau nyawa seseorang, harta benda, dan kehormatan.

Jadi contohnya ketika seseorang yang akan melakukan serangan terhadap orang lain dengan cara membawa celurit yang sudah siap untuk ditebaskan kepada tubuh korban, maka korban dapat melalakukan suatu pelawanan yaitu pembelaan darurat dengan cara melumpuhkan pelaku serangan atau bahkan diperbolehkan bagi korban untuk melakukan tindakan membunuh pelaku jika serangan pelaku sudah sangat membahayakan nyawa korban.

Sebagaimana dikatakan oleh Pompe dalam keadaan normal untuk meniadakan serangan, itu orang harus meminta bantuan dari penguasa, akan tetapi dalam keadaan darurat seperti yang dimaksud dalam Pasal 49 ayat 1
KUHP ia tidak mempunyai kesempatan untuk berbuat demikian, karena itulah maka ia dapat dibenarkan untuk meniadakan sendiri serangan tersebut tanpa bantuan dari alat negara. ${ }^{6}$

Hal ini menunjukkan bahwa apabila seseorang melakukan serangan kepada orang lain dimana orang yang diserang tidak dapat menghindar dan serangan tersebut membahayakan dan mengancam nyawa orang lain, maka dapat dibenarkan orang tersebut melakukan suatu pembelaan darurat, namun pembelaan tersebut harus sesuai dengan unsur -unsur atau syarat-syarat noodweer.

Bahwa rumusan dalam Pasal 49 ayat 1 KUHP tersebut tidak berarti setiap orang secara serta merta dapat melakukan suatu perlawanan dengan alasan pembelaan secara darurat, oleh karenanya Pasal 49 ayat 1 KUHP membatasi tentang noodweer baik dari bagaimana cara melakukan pembelaan ataupun alat yang digunakan untuk melakukan pembelaan. Noodweer dapat menjadi upaya pembelaan darurat yang sah secara hukum jika memenui unsur-unsur noodweer sebagai berikut ${ }^{7}$ :

1. Serangan tersebut bersifat seketika dan bersifat melawan hukum

2. Adanya perlawanan yang seimbang dengan serangan

3. Bersifat berbahaya bagi tubuh, nyawa, arta kekayaan dan kehormatan

\footnotetext{
${ }^{6}$ P.A.F. Lamintang, Loc. Cit. Hlm. 472

7 Patricia Regina Lahe, Pembuktian Noodweer Dalam Tindak Pidana Pembunuhan, Lex Privatum Vol. V/No.3/Mei/2017. Hlm. 47
} 
4. Pembelaan bersifat perlu

5. Perbuatan yang dilakukan untuk melakukan pembelaan itu haruslah dapat dibenarkan.

Syarat-syarat pemebelaan darurat (noodweer) harus memenuhi beberapa asas yaitu :

1. Asas Subsidiaritas

Maksudnya adalah pembelaan yang dilakukan dengan menempuh jalan yang seringan-ringannya, sehinnga tidak merugikan orang lain. ${ }^{8}$

2. Asas Proporsionalitas

Asas ini berkaiatan dengan pembelaan darurat/noodweer harus mempunyai nilai yang seimbang antara perbuatan yang diancam dengan perbuatan yang dialanggar karena Noodweer.

3. Asas demi kepentingan hukum pada saat melakukan pembelaan yang ancamannya berkaiatan dengan Tubuh, nyawa, harta benda dan kehormatan.

Adapun mengapa seseorang yang melakukan noodweer/pembelaan secara darurat itu dapat dibenarkan secara hukum atau kata lainnya tidak dapat dijatuhi pidana. Dalam hal ini penulis akan mengutip dari beberapa pendapat pakar hukum yaitu antara lain ${ }^{9}$ :

1. Pendapat dari pembentuk undang-undang yang menganggap bahwa suatu noodweer itu merupakan suatu hak, hingga seseorang yang melakukan noodweer menjadi tidak dapat dijatuhi pidana.

Penulis dapat mencermati apa yang dikatakan oleh pembentuk undang-undang tersebut merupakan adanya suatu hak dari seseorang untuk melakukan pembelaan terhadap serangan dari pelaku, oleh karena hak dari seseorang yang melakukan pembelaan darurat tidak bersifat melawan hukum.

2. Pendapat kedua dari Binding, dia mengatakan bahwa noodweer merupkan suatu pembelaan yang sah menurut hukum/legitime defense, yang dimaksud sah disini bukan dari bentuk keadilan hukumya atau onrecht melainkan ketidakadilan yang diderita oleh seseorang.

3. Pendapat ketiga adalah pendapat di dalam Memorie Van Toelichting yang artinya perbuatan noodweer itu suatu penyebab yang datangnya dari luar yang perbuatan tersebut tidak dapat dipertanggungjawabkan kepada pelakunya.

4. Pompe mengatakan tentang sebab-sebab mengapa seseorang yang didalam sutau noodweer telah melakukan suatu tindak pidana itu tidak dapat dihukum, kiranya sudah jelas bahwa apa yang telah ia lakukan merupakan haknya yakni haknya yang bersifat alamiah untuk melakukan pembelaan terhadap sesuatu yang

\footnotetext{
8 P.A.F. Lamintang, Op. Cit. Hlm. 243

9 P.A.F. Lamintang, Ibid. Hlm.473
} 
melawan hukum dan bukan merupakan kewajiban sebagaimana yang telah ditentukan dalam Pasal 50 dan 51 KUHP.

Namun pembelaan secara darurat tersebut harus memenuhi unsur sebagaimana yang telah penulis paparkan diatas dan tidak bertentangan dengan tujuan hukum yaitu keadilan, kepastian dan kemanfaatan. Keadilan menurut konsep suum cuique tribuere yang artinya bahwa keadilan adalah suatu keinginan yang terus menerus dan tetap untuk memberikan kepada orang apa yang menjadi bagiannya. Oleh karena itulah, keadilan harus diwujudkan dalam situasi yang konkret yaitu dalam alokasi kepentingan warga masyarakat sedemikian rupa melalui kepatutan, sehingga kehidupan masyarakat yang harmonis tetap dapat dipertahankan. ${ }^{10}$

Merupakan suatu kenyataan bahwa hidup dalam bermasyarakat perlu adanya suatu aturan agar kepentingan yang ada dalam kehidupan masyarakat dapat dilindungi oleh aturan-aturan yang bersifat umum sehingga aturan hukum tersebut baik yang berupa perundang-undangan ataupun hukum yang tidak tertulis yang berisi aturan yang bersifat umum sehingga dapat dijadikan pedoman bagi setiap orang dalam bertingkah laku di kehidupan bermasyarakat.

Adanya aturan semacam itu dan implementasinya menimbulkan adanya kepastian hukum artinya kepastian hukum mempunyai dua pengertian yang pertama adanya aturan yang bersifat umum membuat setiap orang mengetahui perbuatan apa yang boleh atau tidak boleh dilakukan, kedua berupa keamanan hukum bagi setiap orang dari kesewenangan pemerintah karena dengan adanya aturan yang bersifat umum dapat mengetahui apa saja yang boleh dilakukan dan apa yang tidak boleh dilakukan. ${ }^{11}$

Serangan seketika adalah adanya serangan tiba-tiba dari pelaku, dimana serangan tersebut sudah dilakukan walaupun serangan itu belum mengenai tubuh korban, harta kekayaan, dan kehormatan. Maka dari itu perbuatan pembelaan secara darurat dapat dibenarkan secara hukum jika serangannya seketika dimana alat negara tidak dapat melindungi korban, sehingga korban dapat melakukan pembelaan secara darurat yang diperbolehkan oleh undang-undang.

Namun menurut van Hamel, suatu serangan itu dapat disebut sebagai bersifat seketika, yaitu bukan saja jika serangan itu telah benar-benar dimulai, melainkan juga apabila serangan itu telah mengancam secara langsung, walaupun serangannya itu sendiri belum dimulai.

Apa yang disampaikan oleh van Hamel tersebut sudah sesuai dengan rumusan yang terkandung dalam Pasal 49 ayat 1 KUHP, dimana pembelaan darurat dapat dilakukan

\footnotetext{
${ }^{10}$ Peter Mahmud Marzuki, (2008), Pengantar Ilmu Hukum, Jakarta: Kencana Perdana Media Group. Hlm. 133

${ }^{11}$ Ibid. Hlm. 137
} 
ketika serangan benar-benar membahayakan tubuh, nyawa, harta benda dan kehormatan.

Pelaku serangan yang dimaksud adalah manusia dan bukan selain manusia, namun jika manusia itu menyerang dengan menggunakan binatang, binatang disini hanya sebagai media atau alat untuk menyerang seseorang maka dibenarkan orang yang diserang melakukan pembelaan noodweer, karena serangan tersebut telah dilakukan dengan seketika dan atau melawan hukum.

Bahwa mengenai adanya pembelaan dengan perlawanan yang seimbang dengan serangan artinya antara serangan yang membahayakan dengan perlawanan haruslah seimbang, tidak boleh melebihi batas perlawanan yang mengakibatkan adanya ketidakseimbangan antara serangan dengan perlawanan.

Adapun mengenai serangan terhadap tubuh, nyawa, harta benda dan kehormatan sebagaimana masuk dalam unsur/syarat noodweer. Serangan terhadap tubuh disini adalah serangan yang membahayakan yang dapat mengancam terjadinya perubahan pada tubuh baik itu dengan luka, patah, luka lebam dan bahkan mengancam adanya kematian yang termasuk pada serangan terhadap nyawa.

Serangan terhadap harta benda maksudnya adalah adanya suatu serangan terhadap harta kekayaan, yang dimaksud dengan harta kekayaan disini adalah harta yang berupa benda-benda berwujud, bukan termasuk benda tidak berwujud, benda berwujud disni dapat berupa benda yng benar-benar ada wujudnya seperti mobil, uang dll, sedangkan benda tidak berwujud berupa hak-hak yang tidak termasuk pada syarat noodweer. Sebagaimana pendapat dari Pompe mengatakan "perkataan benda itu seperti halnya yang dimaksud di dalam Pasal 362 KUHP, haruslah diartikan sebagai benda yang berwujud". ${ }^{12}$

Bahwa mengenai serangan terhadap kehormatan disni adalah serangan terhadap kehormatan dalam arti seksual bukan kehormatan dalam arti nama baik, suatu penghinaan bukan termasuk pada serangan pada kehormatan yang tidak dapat dilakukan noodweer. Jadi serangan yang dapat dilakukan noodweer adalah serangan yang mengancam kehormatan dalam arti seksual, misalkan pelaku akan melakukan permkosaan kepada seroang wanita sehingga perbuatan pelaku tersebut sangat mebahayakan kehormatan wanita tersebut sehingga hal ini dapat dilakukan pembelaan noodweer dengn cara memberikan perlawanan kepada pelaku. Pembelaan yang demikian dapat dibenarkan oleh hukum, namun jika serangan hanya kepada kehormatan nama baik yang mengakibatkan adanya pencemaran nama baik, maka tidak dibenarkan untuk melakukan pembelaan secara noodweer.

Berbicara mengenai sifat dari serangan yang dapat dilakukan noodweer adalah

12 P.A.F. Lamintang, Op. Cit. Hlm. 497 
serangan yang bersifat seketika dan bersifat melawan hukum.

1. Serangan yang bersifat seketika

Bahwa dalam rumusan Pasal 49 ayat 1 KUHP, pembentuk undang-undang menyatakan bahwa serangan tersebut haruslah bersifat seketika. Menurut pendapat para ahli salah satunya adalah Noyon Langemejer, berkaitan dengan rumusan Pasal 49 ayat 1 KUHP tersebut, pembentuk undang-undang tidak menyatakan tentang syarat adanya serangan harus berupa kekerasan, melainkan yang dimaksud serangan seketika disini adalah berupa suatu bahaya yang dapat mengancam keselamatan secara langsung.

Perlu digaris bawahi adalah ketika serangan tersebut masih berlangsung maka seseorang dapat dibenarkan untuk melakukan noodweer/pembelaan darurat, namun ketika serangan tersebut sudah berhenti dan sudah tidak mengancam atau tidak menimbulkan bahaya maka tidak dibenarkan untuk melakukan noodweer.

Bahkan Simons berpendapat, bahwa serangan yang dimakud dalam Pasal 49 ayat 1 Kitab Undang-undang Hukum Pidana adalah tidak perlu menunggu serangan telah dimulai, dengan alasan jika seseorang menunggu sampai serangan telah dimulai maka biasanya seseorang sudah terlambat melakukan pembelaan.
Kasus penganiayan Pasal 352 KUHP, ketika ada seseorang yang akan melakukan penganiayaan kepada orang lain, katakanlah A melakukan pemukulan kepada B, apabila pemukulan itu sudah dimulai dengan seketika dan membahayakan keselamatan B maka B dapat melakukan pembelaan. Pembelaannya bisa dengan cara memukul balik sehingga A menghentikan serangannya. Apabila A sudah menghentikan serangannya maka B tidak dibenarkan untuk memukul kembali.

Namun apabila A tidak dalam memulai serangan maka $B$ tidak dibenarkan untuk memukul duluan kepada A karena hal itu tidak dapat diartikan sebagai pembelaan darurat.

Contoh kasus serangan secara langsung:

Jika katakanalah A mempunyai maksud untuk melakukan penganiayann kepada B dengan menggunakan alat kayu dengan jarak sekitar 1 meter, maka serangan yang dilakukan oleh A dapat dikatakan sebagai serangan yang mengancam keselamatan.

2. Serangan yang bersifat melawan hukum

Bahwa menurut van Hamel, serangan dapat dikatakan bersifat melawan hukum jika serangan itu dapat menimbulkan penderitaan kepada orang, padahal secara hukum orang tersebut tidak mempunyai kewajiban untuk mendapatkan penderitaan itu. 
Menurut van Hamel, orang tidak dapat dibenarkan untuk melakukan suatu noodweer terhadap pelaksanaan dari suatu tugas jabatan atau pelaksanaan dari suatu tugas pemidanaann yang telah dilakukan secara sah. Akan tetapi noodweer tersebut dapat dibenarkan untuk dilakukan terhadap penyimpangan baik secara formal maupun secara material dari pelaksanaan suatu tugas jabatan atau dari tugas pelaksanaan pemidanaan dan sudah barang tentu hanya apabila syarat-syarat selebihnya dari noodweer itu terpenuhi. ${ }^{13}$

Menurut Pompe berpendapat bahwa perkataan wederrechtelijk dalam Pasal 49 ayat 1 KUHP haruslah diartikan sebagai "bertentangan dengan hukum, yang mempunyai arti yang lebih luas dari pada sekedar bertentanga dengan undangundang, hingga disamping peraturanperaturan perundnagan, juga termasuk ke dalam pengertiannya yaitu peraturan peraturan yang tidak tertulis. ${ }^{14}$

Contoh serangan melawan hukum

$$
\text { Katakanlah A menyerang }
$$
kepentingan hukum B dengan cara bertentangan dengan hukum, misalkan mencuri dll. Sedangkan bila petugas melakukan penyitaan terhdap motor A yang telah diduga sebagai hasil pencurian, maka jika A melakukan pembelaan bukan termasuk kategori pembelaan darurat/noodweer, karena tindakan petugas tersebut dibenarkan oleh hukum.

\section{KESIMPULAN}

Pembelaan darurat atau disebut juga dengan noodweer adalah segala tindakan atau perbuatan seseorang untuk melakukan pembelaan secara darurat karena adanya serangan yang bersifat seketika atau bersifat melawan hukum, dimana serangan tersebut dapat mengancam keselamatan pada tubuh, nyawa, harta benda dan kehormatan.

Namun pembelaan secara darurat tersebut harus memenuhi unsur sebagaimana yang telah penulis paparkan diatas dan tidak bertentangan dengan tujuan hukum yaitu keadilan, kepastian dan kemanfaatan.

\section{DAFTAR PUSTAKA}

Lamintang, P.A.F, 2014, Dasar-dasar Hukum pidana Indonesia, Sinar Grafika, Jakarta Timur.

Marzuki Mahmud Peter, 2013, Penelitian Hukum, kencana prenada media group, Jakarta.

Marzuki Mahmud Peter, 2008, Pengantar Ilmu Hukum, kencana prenada media group, Jakarta.

Masruchin Ruba`i, 2015, Buku Ajar Hukum Pidana, Media Nusa Creative, Malang.

Patricia Regina Lahe, 2017, Pembuktian Noodweer dalam tindak pidana pembunuhan, Lex Privatum Vol. V/No.3/Mei/2017.

${ }^{13}$ P.A.F. Lamintang, Op. Cit. Hlm.477

${ }^{14}$ P.A.F. Lamintang, Op. Cit. Hlm. 478 